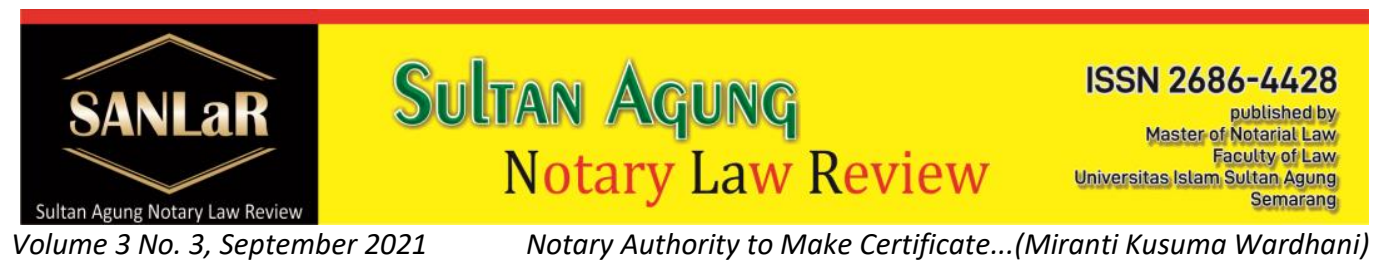

\title{
Notary Authority to Make Certificate of Heir Based On Notary Positions
}

\author{
Miranti Kusuma Wardhani*) \\ ${ }^{*}$ Faculty of Law, Universitas Islam Sultan Agung (UNISSULA) Semarang, E-mail: \\ miranti.87roesamsi@gmail.com
}

\begin{abstract}
Before the Act No. 30 Of 2004 about notary Occupation being progress, there is no special regulation that is becoming the basic for Notary authority to make the Bank statement for heir in practically in Indonesia. After the Act No. 30 of 2004 about notary Occupation being progress, the notary authority to make the bank statement for heir is not arranged expressly in section 15 sentence (2). In consequence require by an analysis to notary authority in making Bank statement for heir especially after the Act No. 30 Of 2004 about notary Occupation being progress. This research uses the empirical approach juridically. The example is taken by non random purpose sampling. Analyze done by descriptive, to analyze the notary authority in making bank statement for heir after the Act No. 30 Of 2004 about notary Occupation being progress. Target of this research is to know and studying of arrangement of notary authority in making Bank statement for heir in pursuant to number Act No. 30 of 2004 about notary Occupation, the strength of verification of Bank Statement for Her which made by some different notary people to heir in someone to heir and third party and also sanction to notary and notary responsibility if wronging in Bank Statement for Heir. From research result known that base of Notary authority make the bank Statement for Heir customary law since away back caused a notary assumed by as of side knowing about hereditary law, verification Bank Statement depend on wisdom of justice and sanctions and also notary responsibility if wronging in making Bank Statement Heir that is Section 1365 of the Civil Code. Suggested that a notary authority in making Bank Statement Heir formally cover the authority of functional and heir criterion able to make the Bank statement heir before notary.
\end{abstract}

Keywords: Bank; Statement; Heir; Notary; Authority. 


\section{Introduction}

In the State of Indonesia, the law related to inheritance issues is still pluralism so that, regarding inheritance law, three different inheritance law systems still apply, namely the inheritance law regulated in Burgerlijk Wetboek (BW) which is intended for European and Eastern Chinese residents; then there is inheritance law which is regulated based on customary law where the provisions are regulated according to their respective regions according to local customs; and inheritance law which is regulated based on religion, namely Islam, where the provisions are subject to Islamic law and are intended for people who are Muslim. Based on the provisions of Article 49 of Act No. 3 of 2006 concerning Amendments to Act No. 7 of 1989 concerning Religious Courts ${ }^{1}$. In the current legislation in Indonesia, there are no rules that specifically regulate the Inheritance Certificate, as well as in the Notary Position Regulation ${ }^{2}$, Act No. 30 of 2004 concerning the Notary Position does not mention let alone discuss and regulate the Inheritance Certificate. The law is a regulation that regulates the position of a notary, in Act No. 30 of 2004 it contains a number of authorities regarding the position of a notary, the authority is stated in Article 15 paragraph (1).

\section{Research Methods}

This research is a normative legal research (doctrinal legal research). As with the type of normative research, the approach methods used in this research are the statute approach and the conceptual approach. ${ }^{3}$ Research sources can be divided into primary, secondary, and tertiary legal sources. The collection of legal materials is done by means of library research. ${ }^{4}$ The results of the analysis of legal materials will be interpreted using systematic and grammatical interpretation methods. ${ }^{5}$

\section{Result and Discussion}

According to the Notary in Cirebon City, the Inheritance Certificate is basically not an authentic deed but is an underhand deed in the form of a certificate made by a notary as a public official. Because it is not an

\footnotetext{
${ }^{1}$ Act No. 3 of 2006 concerning Amendments to Act No. 7 of 1989 concerning Religious Courts.

2 Deen, Thaufiq., Ong Argo Victoria \& Sumain. (2018). Public Notary Services In Malaysia. JURNAL AKTA: Vol. 5, No. 4, 1017-1026. Retrieved from http://jurnal.unissula.ac.id/index.php/akta/article/view/4135

${ }^{3}$ I Made Pasek Diantha, Metodologi Penelitian Hukum Normatif, Prenada Media Group, Jakarta, 2016, p. 156

${ }^{4}$ Soerjono Soekanto dan Sri Mamudji, Penelitian Hukum Normatif, Rajagrafindo Persada, Jakarta, 1985, p. 41

${ }^{5}$ Sudikno Mertokusumo, Penelitian Hukum, Liberty, Yogyakarta, 2005, p. 47
} 
authentic deed, actually according to Research, a Certificate of Inheritance can be made by anyone other than a notary who has legal skills or not. Certificate of Inheritance, according to a Notary in Cirebon, includes a private deed and not an authentic deed, but not just anyone can make it. For the East-Foreign group, in practice, a Certificate of Inheritance is made by a notary based on a statement made by an interested party as the basis for a notary to make a Certificate of Inheritance on behalf of the interested party. Matters that must be included in the beginning of the deed are determined by Article 38 paragraph (2) of Act No. 30 of 2004. According to paragraph (2), the beginning of the deed or the head of the deed must contain the title of the deed, deed number, time, day, date, month and year as well as the full name and domicile of the Notary 6 .

As for the making of a Certificate of Inheritance as an effort to find out the share of inheritance, one example is aimed at making each heir know his share in connection with the possibility of the entry of other new heirs. In this case the inheritance has not been transferred by the heirs. if the applicant fulfills several requirements including showing the Identity Card (KTP) of each heir, if possible the ID card of the heir and several witnesses who know about the position of the heir and the legal heirs, both living and dead, along with the following: their respective heirs.

The appointment of an ID card, according to the Notary, is an absolute must so that the Notary knows the truth about the identity of the heirs and heirs so that problems can be avoided in the future caused by false identities, either wholly or partly by the heirs or heir?

If possible, according to the notary, the notary can request that the applicant, who in this case is the heir, bring in a witness who really knows the identity of the heir and the heirs according to the ID card so that if a problem occurs in the future, the notary can submit the strength of the testimony of witnesses who were also present.. A notary in order to make a Certificate of Inheritance obtains information from witnesses who really know about the family structure of the heir and who the heirs are. A notary must pay attention and really check the quality of the witness so that the witness who is asked for information by the notary before making a Certificate of Inheritance is really a witness who knows for

\footnotetext{
${ }^{6}$ A Chuasanga, Ong Argo Victoria. (2019). Legal Principles Under Criminal Law in Indonesia Dan Thailand, Jurnal Daulat Hukum, Vol 2, $\quad$ No 1 (2019) http://jurnal.unissula.ac.id/index.php/RH/article/view/4218

${ }^{7}$ Ong Argo Victoria, (2018) Waqf Al-Nuqūd In Indonesia (In Law Perspective), Jurnal Pembaharuan Hukum Vol 5, No 1 Universitas Sultan Agung, http://jurnal.unissula.ac.id/index.php/PH/article/view/2999
} 
sure the condition of the heir's family including who is the heir of the heir. Making a Certificate of Inheritance by a notary is a reasonable and appropriate legal act because the notary has been known by the public as an official who is authorized to make a deed that will have legal consequences in the future.

Another factor that makes it possible to make a double inheritance certificate for an heir according to the study is the non-functioning of the role of the Department of Law and Human Rights as a data repository for heirs' wills throughout Indonesia because the Department will not inform the notary that the data requested by the notary has already been requested by another notary to make a Certificate of Inheritance. Neither the law nor the customs that have been in force so far have not explicitly regulated the party authorized to make a Certificate of Inheritance if there is more than one heir. Because in the absence of restrictions on who has the right to appear before a notary and which notary has the right to make a Certificate of Inheritance, each heir who feels entitled to an inheritance can be free to appear before a notary to ask for a Certificate of Inheritance to be made authorized to make a Certificate of Inheritance because there are no restrictions regarding this matter. This will result in the emergence of a double Inheritance Certificate for an heir which will cause problems in the distribution of the inheritance left by the heir. So it is in place if this happens, it is the authority of the Court to test and prove which of the Inheritance Certificates on behalf of the testator will be implemented to determine and divide the inheritance.

\section{Closing}

The Civil Code and Act No. 30 of 2004 concerning the Position of a Notary do not explicitly regulate the authority of a notary in making a Certificate of Inheritance, however, based on the authority of a notary regulated by Article 15 of Act No. 30 of 2004 which is very broad in making a deed of all deeds, can be used as a basic guideline for a notary to make a Certificate of Inheritance so far based on customary law. It is up to the Court's discretion to determine which Inheritance Certificate is authentic against an heir. The witness and the responsibility of the notary if he makes a mistake in making the Inheritance Decree is on the basis of Article 1365 of the Civil Code because the Notary Position Act only regulates the sanctions and responsibilities of the notary if the authentic deed made by the notary only applies as a private deed and does not regulate sanctions and the responsibility of the notary in making the deed under the hand. 


\section{References}

Journal:

[1] A Chuasanga, Ong Argo Victoria. (2019). Legal Principles Under Criminal Law in Indonesia Dan Thailand, Jurnal Daulat Hukum, Vol 2, No 1 (2019) http://jurnal.unissula.ac.id/index.php/RH/article/view/4218

[2] Deen, Thaufiq., Ong Argo Victoria \& Sumain. (2018). Public Notary Services In Malaysia. JURNAL AKTA: Vol. 5, No. 4, 1017-1026. Retrieved from http://jurnal.unissula.ac.id/index.php/akta/article/view/4135

[3] Ong Argo Victoria, (2018) Waqf Al-Nuqūd In Indonesia (In Law Perspective), Jurnal Pembaharuan Hukum Vol 5, No 1 Universitas Sultan http://jurnal.unissula.ac.id/index.php/PH/article/view/2999

Agung,

Books:

[1] Pitlo, Hukum Waris Menurut UU Hukum Perdata Belanda, Intermasa, Jakarta,1994.

[2] Affandi, Ali, Hukum Waris, Hukum Ketuarga, Hukum Pembuktian, BinaAksara, Jakarta, 1983.

[3] Bauer, Jeffrey C, Role Ambiguity and Role Clarity: A Comparison of Attitude in Germany and The United States, Clermont, University of Cincinnati, 2003.

[4] Benyamin Asri dan Thabrani Asri, Dasar-dasar Hukum Waris Barat (Suatu Pembahasan Teori dan Praktik), Tarsito, Bandung, 1988.

[5] Bushar Muhammad, Pokok-Pokok Hukum Adat, Jakarta, PT.Pradnya Paramita,1995.

[6] Bushar Muhammad, Pokok-Pokok Hukum Adat, Jakarta:PT.Pradnya Paramita,1995.

[7] Drs. C.S.T. Kansil, Pengantar IImu Hukum dan Tata Hukum Indonesia, Jakarta, Balai Pustaka, 1989.

[8] Dwi Cahyani, Tinuk, Hukum Waris dalam Islam, Malang, Universitas Muhammadiyah Malang, 2018.

[9] Efendi Perangin, Hukum Waris, Rajawali Pers, Jakarta, 2003.

[10] Gregor van der Burght diterjemahkan oleh F. Tengker, Hukum Waris, Citra Aditya Bakti, Bandung, 1995.

[11] Habib Adjie, Hukum Notaris Indonesia Tafsir Tematik Terhadap UU. 30 Tahun 2004 Tentang Jabatan Notaris, Bandung, Refika Aditama, 2011.

[12] Hartono Soerjopratilnyo, Hukum Waris Testamentair, Seksi Notariat Fakultas Hukum Universitas Gajah Mada, Yogyakarta, 1982.

[13] Idris Ramulyo, Mohd., Beberapa Masalah Pelaksanaan 
Hukum Kewarisan Perdata Barat ( Burgelijke Wetboek ), Sinar Grafika, Jakarta, 1993.

[14] Imam Gunawan, Metode Penelitian Kualitatif: Teori dan Praktek, Jakarta, PT Bumi Aksara, 2015.

[15] Kanfer, R, 1987, "Task Specific Motivation: An Integrative Approach to Issues of

[16] Kie, Tan Thong, Studi Notariat - Serba Serbi Praktik Notaris, Ichtiar BaruVan Hoeve, Jakarta, 2000.

[17] M.Solly Lubis, Filsafat IImu Dan Penelitian, Bandung: Mandar Maju, 2007.

[18] Malpraktik Notaris dan Hukum Pidana, Agung, Semarang, 1991.

[19] Mayorat merupakan seorang anak tertua menjadi ahli waris, baik itu perempuan maupun laki-laki

[20] Measurement, Mechanisms, Processes, and Determinants", Journal of Social and Clinical Psychology, 5/1987:237-

[21] Mertokusumo, Sudikno, Beberapa Asas Pembuktian dan Penerapannya Dalam Praktik, Liberty, Yogyakarta, 1980. Metode Penelitian Hukum, Ghalia Indonesia,Jakarta, 1982.

[23] Moleong, Lexy J.,Metodologi Penelitian Kualitatif, Penerbit PT Remaja Rosdakarya. Offset, Bandung, 2007.

[24] Mourik, J.A van diterjemahkan oleh F. Tengker, Studi Kasus HukumWaris, Eresco, Bandung, 1993.

[25] Muhammad Ali Ash-Shabuni, Pembagian Waris Menurut Islam, Di Terjemahkan Oleh Gema Insani Press, Jakarta, 1995.

[26] Nasution, S., Metode Penelitian Naturalistik-Kualitat, Bandung, Tarsito, 1992.

[27] Notodisoerjo, R. Soegondo, Hukum Notaiat Di Indonesia SuatuPenjetasan, Rajawali Pers, Jakarta, 1982.

[28] Oemarsalim, Dasar-dasar Hukum Waris Di Indonesia, Rineka Cipta,Jakarta, 1991.

[29] Perangin, Effendi, Hukum Waris, RajaGrafindo Persada, Jakarta, 2003.

[30] Peter Mahmud Marzuki, Pengantarllmu Hukum, Kencana, Jakarta, 2008.

[31] Pitlo, A. alih bahasa oleh M. Isa Arief, Hukum Waris Menurut Kitab Undang-undang Hukum Perdata Belanda Jilid I, Intermasa, Jakarta,1994.

[32] Robbins, Stephen P, Organizational Behavior, 9th Edition. Upper Sadle River, Prentice Hall Inc, New Jersey, 2001.

[33] Salman, Otje, Kesadaran Hukum Masyarakat Terhadap Hukum waris, Bandung, PT Alumni, 2007. 
[34] Satrio, J., Hukum Waris, Alumni, Bandung, 1992.

[35] Satrio. J, Hukum Waris, Alumni, Bandung, 1992, hal 8.

[36] Shidarta, Hukum Perlindungan Konsumen Indonesia, Edisi Revisi, (Jakarta: Gramedia Widiasarana Indonesia, 2006.

[37] Sjarif, Surini Ahlan, Intisari Hukum Waris Menurut BW, Ghalia Indonesia, Jakarta, 1983.

[38] Soekanto, Soerjono dan Mamudji, Sri, Penelitian Hukum Normatif SuatuTinjauan Singkat, Raja Grafindo, Jakarta, 1998.

[39] Soekanto, Soerjono, Penelitian Hukum Normatif Suatu Tinjauan Singkat, Raja Grafindo, Jakarta.

[40] Subekti, R., Ringkasan Tentang Hukum Keluarga dan Hukum Waris, Intermasa, Jakarta, 1990.

[41] Sugiono, Metode Penelitian Administrasi, Bandung, Alfabeta, 2001.

[42] Tedjosaputro, Liliana, Hukum Waris Menurut Surat Wasiat (AdTestamento), Agung Press, Semarang, 1991.

[43] Thong Kie, Tan, Studi Notariat - Serba Serbi Praktik Notaris, Ichtiar Baru Van Hoeven Jakarta 2000.

[44] Tim penyusun Kamus Pusat Bahasa, Kamus Besar Bahasa Indonesia,.ed.3, Jakarta, balai Pustaka, 2010.

[45] Yudha Bhakti Ardiwisastra, Penafsiran dan Konstruksi Hukum, PT.Alumni, Bandung. 2012.

Regulation:

[1] Act No. 3 of 2006 concerning Amendments to Act No. 7 of 1989 concerning Religious Courts.

[2] Act No. 30 of 2004 concerning the Position of a Notary.

[3] Civil Law. Jakarta, 1999.

[4] Constitution of 1945, Amendment Result, Sinar Graphic Publisher, Jakarta. 2002. 